\title{
The impact of the Forest Stewardship Council (FSC) pesticide policy on the management of leaf-cutting ants and termites in certified forests in Brazil
}

\author{
José C. Zanuncio $^{1}$ • Pedro G. Lemes ${ }^{2}$. Luciana R. Antunes ${ }^{3}$ • José Luiz S. Maia ${ }^{4}$. \\ José Eduardo P. Mendes ${ }^{5}$ • Kaliana M. Tanganelli ${ }^{3}$ - Jonas Felipe Salvador ${ }^{6}$. \\ José E. Serrão ${ }^{7}$
}

Received: 25 September 2015 / Accepted: 14 March 2016/Published online: 30 March 2016

(C) INRA and Springer-Verlag France 2016

- Key message The recommendations accompanying pesticide derogations from the FSC are not efficient for the management of leaf-cutting ants and termites in certified forest plantations in Brazil compared with chemical control using insecticides. FSC recommendations ignore the biological and ecological features of pests and forest plantations in Brazil when they set global rules for forest certification.

\section{Handling Editor: Aurelien Salle}

Contribution of the co-authors: Pedro G. Lemes: wrote the manuscript and coordinated the research project.

Luciana R. Antunes: wrote and supervised the work.

José Luiz S. Maia: José Eduardo P. Mendes and Jonas Felipe Salvador: wrote and contributed with the experience of Brazilian forest companies. Kaliana M. Tanganelli: supervised and contributed with certification part of manuscript.

José E. Serrão: wrote the manuscript

\author{
José C. Zanuncio \\ zanuncio@ufv.br \\ Pedro G. Lemes \\ pedroglemes@hotmail.com \\ Luciana R. Antunes \\ lucianarantunes@gmail.com \\ José Luiz S. Maia \\ jose.maia53@terra.com.br \\ José Eduardo P. Mendes \\ jose.mendes@fibria.com.br \\ Kaliana M. Tanganelli \\ kaliana@ipef.br \\ Jonas Felipe Salvador \\ jonas.salvador@duratex.com.br
}

\section{Introduction}

To prevent the trade of illegally logged timber and to promote sustainable forest management systems with social and environmental integrity, voluntary certification systems such as the Forest Stewardship Council (FSC) have been developed (Overdevest and Rickenbach 2006; Basso et al. 2011). The Brazilian Program of Forest Certification (CERFLOR) is the best-known forest certification system in Brazil, while the FSC and the Programme of the Endorsement of Forest Certification (PEFC) are the most important international systems (Basso et al. 2011; Meidinger 2011). The FSC certification system began in 1993 with standards set for managed forests around the world. The aim of the system was to strike a balance between social, environmental, and economic issues central to forest management (Rua et al. 2009). In 2015, there were approximately 181 million ha of forests holding FSC certification in 80 countries. Brazil has the largest forest area certified by

José E. Serrão

jeserrao@ufv.br

1 Departamento de Entomologia, Universidade Federal de Viçosa, 36570-900 Viçosa, Minas Gerais, Brazil

2 Instituto de Ciências Agrárias, Universidade Federal de Minas Gerais, 39404-547 Montes Claros, Minas Gerais, Brazil

3 Instituto de Pesquisas e Estudos Florestais (IPEF), Avenida Pádua Dias, 11, Caixa Postal 530, 13400-970 Piracicaba, São Paulo, Brazil

4 Gerência de Sustentabilidade Madeira, Duratex SA, São Paulo, Brazil

5 Centro de Tecnologia, Fibria S.A, São Paulo, Brazil

6 Proteção Florestal, Duratex SA, São Paulo, Brazil

7 Departamento de Biologia Geral, Universidade Federal de Viçosa, 36570-000 Viçosa, Minas Gerais, Brazil 
this system in Latin America, followed by Chile, Uruguay, and Bolivia (FSC 2015a). In 2014, Brazil had $63 \%$ (4.88 mi ha) of its plantations certified, including 2.6 million ha under FSC, 1.7 million ha under both FSC and CERFLOR/PEFC, and 0.58 million ha under CERFLOR/PEFC (IBA 2015). In 2014, there were 7.74 million ha of forest plantations in Brazil, $71.9 \%$ with Eucalyptus spp., $20.6 \%$ with Pinus spp. and the remaining area with Acacia spp. including Araucaria angustifolia (Bertol.) Kuntze, Hevea brasiliensis L., Populus spp., Tectona grandis L. f., and Schizolobium amazonicum Huber ex Ducke (IBA 2015).

An organization acquiring FSC certification should adhere to its principles and policies, which reflect the organization's values and aspirations for sustainably managed forest systems. These principles aim to maintain both biodiversity and productivity while also ensuring the livelihood of local populations. The predefined criteria for certification include regulations that prescribe, for example, the methods to be used for forest establishment (Ericksson et al. 2007). Certification is important for sustainable forest management, and it may also permit access to new markets through improved business management (IBA 2015). In addition, certification ensures compliance of forest management activities with local social and environmental laws, especially those that relate to protected areas and conservation estates (Basso et al. 2012). In particular, the FSC "Principles and Criteria" include standards for forest certification, such as the "Pesticide Policy," which describes the relevant requirements of FSC with regard to the use of pesticides for forest management. The standards consist of the following three central elements: (a) the identification and prevention of "highly hazardous" pesticide use, (b) the promotion of "nonchemical" methods for pest management as an integrated strategy, and (c) the proper use of pesticides (FSC 2007). The indicators for assessing the degree of danger for using a particular product are included in this policy along with a list of products. Active ingredients classified as "highly hazardous", according to FSC's evaluation, are therefore prohibited from use in certified forestry. As a result, an organization seeking certification will need to halt its use of the active ingredients listed in the policy (Tabaković-Tošić et al. 2011).

Certified companies are required to follow the prescriptions of the FSC Pesticides Policy, and if a prohibited product is needed, an application for derogation must be submitted (FSC 2007). Through the derogation process, a specific need for the active ingredient for managing a specific insect, weed and/or disease must be demonstrated (FSC 2012). The pesticide for which the derogation is being applied must be shown to be the only economically, environmentally, and socially viable as well as technically feasible method to control the specific pest that is affecting forest health or productivity. Following the derogation approval, requirements and conditions are set for the use of the prohibited pesticide. The list of active ingredients prohibited from use in FSC-certified forest areas is reviewed periodically and was last updated in 2015 (FSC 2015b). Several active ingredients used in forest plantations, including deltamethrin, fenitrothion, fipronil, and sulfluramid, which are used for leaf-cutting ant and termite management in Brazilian plantation forests, are prohibited (FSC 2015b). Consequently, forestry companies in Brazil and elsewhere face difficulties in adhering to the criteria imposed by the certification systems on the use of chemical pesticides due to the lack of equivalent alternatives for the integrated management of several pests (Govender 2002; Carnegie et al. 2005; Rolando et al. 2011). This is especially true for leaf-cutting ants and termites in South America where these insects are major pests for most tree species planted throughout the continent, and there are few efficient techniques available to control and manage them (Della Lucia et al. 2013).

The active ingredients in the pesticide derogation for managing leaf-cutting ants in Brazil are sulfluramid, fipronil (both used in granulated baits) and deltamethrin (used in powder formulation). Fipronil used for the management of root termites (as dispersible granules or via root immunization) is also used in derogation (FSC 2015c). Fipronil and sulfluramid were included in the prohibition list due to their acute toxicity to mammals and birds. Deltamethrin was also prohibited for this reason and because it is considered an endocrine disrupting chemical, exhibiting acute toxicity to aquatic organisms (FSC 2015b, d).

The objectives of this work are to (1) present an overview of the biology, damage and management of leaf-cutting ants and termites in Brazilian forest plantations and (2) present and discuss recommendations provided by FSC that accompany its approval of the derogation for using deltamethrin, fipronil, and sulfluramid (including the current methods, alternatives, conditions, side effects, and application techniques) that are considered "highly hazardous" pesticides used for managing leafcutting ants and termites in certified forest plantations in Brazil.

\section{Leaf-cutting ant and termite biology and plantation damage overview}

\subsection{Leaf-cutting ants}

The leaf-cutting ant species of the genus Atta (Hymenoptera: Formicidae), which occur in Eucalyptus spp. (Myrtaceae) plantations in Brazil, include Atta laevigata (F. Smith, 1858), Atta sexdens (L., 1758) (including three subspecies), and Atta cephalotes. Those of the genus Acromyrmex include 11 species (Boaretto and Forti 1997). Leaf-cutting ants also present a threat to other forest crops in the country, including Pinus spp. (Pinaceae) (Hernández and Jaffé 1995; Cantarelli et al. 2008), Hevea brasiliensis L. (Euphorbiaceae) (Schroth et al. 2003), Tectona grandis L.f. (Lamiaceae) (Passos et al. 2006), and others still unpublished. These ants may be selective during foraging (Della Lucia et al. 2013). 
The ants have several adaptations that make their management and control difficult compared to methods commonly used for other pests. These adaptations consist of a complex colonial structure, foraging, fungus cultivation, hygiene, and social organization (Della Lucia et al. 2013). Leaf-cutting ants are social insects, and their colony acts as a superorganism, featuring a long-living queen that is responsible for the structure of the colony and for laying eggs. The progeny, which include the workers, have different functions within the colony; for example, winged males and females are responsible for forming new colonies (Della Lucia 2011). Therefore, techniques that control individuals other than the queen are unlikely to be successful unless there is a strong and negative impact on the queen or workers are killed faster than the queen can lay eggs, compromising the nest sustainability (Della Lucia et al. 2013; Zanetti et al. 2014). In addition, leaf-cutting ants do not feed directly from the leaves but from the symbiotic fungus cultivated inside their colony. As a result, eliminating their fungal garden may be an alternative control measure (Zanetti et al. 2014). However, it is difficult to reach the fungal garden with contaminants (e.g., pesticides, fungus pathogen, or competitor) due to the ant nest structure, social organization, and high level of hygiene (Della Lucia et al. 2013).

The economic injury level of leaf-cutting ants is between 13.4 and $39.2 \mathrm{~m}^{2}$ of nests/ha in Eucalyptus plantations in Minas Gerais State, Brazil (Souza et al. 2011), but this level may vary in areas with seedlings or regrowth forest. Just one nest may reduce wood production from 0.04 to $0.13 \mathrm{~m}^{3} / \mathrm{ha}$ (Souza et al. 2011), and the losses caused by the insects may vary with plant age and the intensity of attack. For instance, defoliation during the first year of a plantation may cause tree mortality (Anjos et al. 1993). Pinus caribaea Mor. plants damaged by A. laevigata showed a negative correlation between nest density and timber volume (Hernández and Jaffé 1995). In addition, 1-month-old seedlings of Pinus taeda L. (Pinaceae) with complete defoliation by leaf-cutting ants suffered losses of $13.3 \%$ in height and $20.0 \%$ in diameter 1 year later (Reis Filho et al. 2011). An Acromyrmex attack reduced the growth in diameter and height of $P$. taeda during the first 2 years of planting (Cantarelli et al. 2008). These numbers illustrate a local situation because specific factors may influence the economic injury level; therefore, the characteristics of the plantations and the level of infestation per forest management unit should be considered (Mendes 2004).

Leaf-cutting ants commonly found in forest plantations can be easily controlled using granulated baits with sulfluramid or fipronil with the typical application of $10 \mathrm{~g}$ of bait for each square meter of loose soil for each nest (Zanuncio et al. 1997, 1999; Delabie et al. 2000; Zanetti et al. 2003a, b). The first application is usually completed before harvesting or planting or as a way to protect the plant sprouts. The second is applied against the remaining small-sized ant nests and may involve baits in mini-plastic bags (MPBs) or systematic bait distribution in the area. The control of leaf-cutting ants is concentrated during periods of low humidity over the course of the year, when ant foraging activity is higher. However, fogging is an alternative method to using bait: it is typically applied during rainy periods for use against large nests such as those of the genus Atta; however, its use is associated with significant environmental costs (Cruz et al. 1984; Anjos et al. 1998).

\subsection{Termites}

Termite species (Isoptera) found in eucalypt plantations in Brazil that are classified as pests include Armitermes enamignathus Silvestri, 1901, Coptotermes testaceus (L., 1785), Cornitermes cumulans (Kollar, 1832), Cylindrotermes sp. Holmgren, Heterotermes tenuis (Hagen, 1858), Nasutitermes aquilinus (Holmgren, 1910), Neocapritermes opacus (Hagen, 1858), Procornitermes araujoi Emerson, 1952, Procornitermes striatus (Hagen, 1858), Procornitermes triacifer (Silvestri, 1901), and Syntermes nanus Constantino, 1995 (Constantino 2002), although other species may also be present (Berti Filho 1993; Amaral-Castro et al. 2004).

Like ants, termites are social insects that build nests for the purpose of colony protection and food storage and to maintain ideal conditions for the development of its individuals. Termite colonies are comprised of two castes: a reproductive one, formed by the winged king and queen, which is responsible for the proliferation of the colony, and the wingless caste, with workers serving in different functions. Unlike a colony of leaf-cutting ants, the termite queen can be replaced. Additionally, the food collected by workers is consumed by both the workers and the dependent individuals living in the colony. As a forestry pest, termites feed on wood, dead or alive, as well as roots and other organic matter (Berti Filho 1993) while symbiotic organisms (such as protozoa, bacteria, and /or fungi) living in their guts digest the cellulosic material. Some species may also grow a fungal garden for food (Berti Filho 1993).

Despite being beneficial organisms, especially for nutrient cycling, termites are pests in forestry due to the damage they cause in virtually all plant developmental stages (Berti Filho 1993). Detailed information on the biology of these insects, including management strategies and an identification key for the most common species, are available (Berti Filho 1993).

Fipronil concentrations of 0.35 and $0.5 \%$ are the most common and effective treatments for controlling root termites in Brazilian forestry. The treatment is applied by soaking the roots of seedlings with the fipronil solution before planting or applying it around the planted seedlings; 
this can provide up to 6 months of protection against the pests (Wilcken and Raetano 1995).

\section{Brazilian derogation process and alternatives proposed by FSC}

A derogation allows the temporary use of pesticides rated as "highly hazardous" by FSC in its pesticide policy. It also seeks recommendations for possible alternative methods for controlling insects and/or diseases in forest plantations in order to obtain and/or maintain certification. The Brazilian derogation procedure was initially developed as a cooperative effort between forestry companies and academic researchers. Significant data that included documentation on product characteristics, information and statistics of incidence, severity, damage, and losses caused by pests were gathered and prepared. This process also consisted of feasibility studies and results of tests using non-chemical or less toxic alternatives, pest management methods, cost-benefit analysis, and evaluations of social and environmental impacts.

Efforts were also made to better understand the bioecological uniqueness of forest plantations and leafcutting ants and termites in Brazil. In addition to the strict legal requirements regarding the registration and use of pesticides in this country, a significant body of knowledge produced over the years was available on integrated pest management and forest entomology. Indeed, integrated pest management has not yet fully focused on the specific requirements for forest certification in Brazil; however, the search for alternatives to overcome such problems was satisfactory as the derogations were approved. The first Brazilian derogation process, in which it took about 2 years for the approval of the majority of derogation requests, included deltamethrin, fenitrothion, fipronil, and sulfluramid for leaf-cutting ant control and fipronil for termite control. FSC recommendations were followed after the approval.

All reviewed alternatives discussed in this opinion paper are based on the conditions and recommendations presented by FSC expert advisers to Brazil at the time of derogation approval for those active ingredients (Isering and Neumeister 2010). The recommendations have been grouped and summarized into three major points to facilitate the discussion, as follows: (1) reduction in the amount and number of pesticide applications, (2) reduction in the side effects to nontarget organisms and people, and (3) development of control alternatives using biological and/or non-chemical methods. The full list of proposed alternatives and recommendations may be reviewed by consulting Isering and Neumeister (2010). The viability of the alternatives is discussed through literature review. In some cases, the experiences of the authors and collaborators were considered in addition to data from unpublished academic documents (e.g., dissertations and theses).

\section{Leaf-cutting ant control}

\subsection{Reduction in the amount and number of pesticide applications}

Preventive control reduces crop damage, occurrence, reinfestation, environmental damage, and the impact of a later control measure. Forest plantations are particularly vulnerable to attack by leaf-cutting ants during the first year (Pikart et al. 2011); therefore, the insects must be controlled to avoid irreparable losses. The critical acceptable density of the nests is not the one that reaches the economic injury level; instead, it is the density that reaches that injury level after growth has occurred during a specific period of time. Further, a sampling plan is vital for the management of leaf-cutting ants to determine the spatial distribution of the nests, making the control decision more accurate, which in turn reduces the amount of pesticide that must be applied (Caldeira et al. 2005).

A reduction in the use of sulfluramid baits must be preceded by a reduction in the infestation, which may require a greater application of bait in the plantation stage. Reduction goals should be established considering each silvicultural stage. Proper application with dosage optimization (obtained through experimentation) and monitoring are essential methods for reducing the use of leaf-cutting ant insecticides. In the long term, this makes it possible to reach a stability period with a low level of ant nest infestation, making it feasible to reduce the number of applications. However, compulsory bait application reduction goals may actually increase infestation levels and thus lead to a subsequent increase in insecticide use.

Sampling and monitoring are important tools for reducing the number of pesticide applications. Samples with transect bands having a recommended distance of $96 \mathrm{~m}$ between the bands showed similar results compared to an exhaustive census of nests within the plantation (Almeida Reis et al. 2010). Additionally, while the line transects method results in lower accuracy than the previous method, it can provide valuable insights for pest management (Zanuncio et al. 2004; Sossai et al. 2005). Monitoring must also consider the areas surrounding the plantation because the ants may live outside but forage inside the plantations (Cantarelli et al. 2006). At a minimum, nests located within $50 \mathrm{~m}$ from the edge of the plantation should be controlled, including native vegetation areas (Magistrali and Anjos 2011).

Another proposed alternative for reducing the use of ant insecticide includes the use of plastic bags and MPBs. The plastic bag bait containers can hold approximately $50 \mathrm{~g}$ of ant baits, protecting them against rain, moisture, and the action 
of wild animals; however, they have not been used because of higher costs compared to MPBs (Almeida 1982). MPBs are small plastic bags containing granulated bait, usually between 5 and $10 \mathrm{~g}$ (Parma and Ulhüa 1986). The main advantage of this technique is that it is not necessary to locate a specific nest and apply the insecticide. Instead, an initial sampling at the time of planting should be conducted to define the infestation rate, which will inform the density of plastic bags per hectare (Laranjeiro et al. 1986). In addition to these advantages, intact MPBs may remain in the field for up to 4 months and prevent an ant reinfestation (Laranjeiro et al. 1986). The most effective dose of MPBs for controlling Acromyrmex crassispinus (Forel, 1909) in Eucalyptus urophylla $\times$ Eucalyptus grandis hybrid plantations was $5 \mathrm{~g}$ with a higher carrying rate than with $10 \mathrm{~g}$ of bait (Ukan 2008). The use of MPBs is justified in situations such as for the control of small Atta nests at the initial stage, for the control of Acromyrmex in areas with thick undergrowth hindering its location (Zanetti et al. 2003a) and on humid and rainy days when the direct application of bait has a low efficiency.

\subsection{Reduction in the side effects to non-target organisms and people}

The forestry sector was a pioneer in replacing bait that was based on dodecachlor with sulfluramid (Zanuncio et al. 1992, 1993). Sulfluramid is less toxic with slow action, low persistence in the environment and rapid degradation. Nevertheless, it needs to be applied properly to reduce the impact on certain ant species, especially other Formicidae, a diverse and important ant family (Ramos et al. 2003). The method of systematically applying bait may have a higher impact on the diversity of this insect group in comparison to localized control (Ramos et al. 2003). Therefore, the method of directly applying bait along tracks and on ant nests on dry days has prevailed. This direct application has resulted in an increased level of bait uptake by the ants, a lower quantity of bait applied per area unit and a reduction in potential environmental contamination and adverse effects on non-target organisms. However, the level of difficulty in locating small nests, such as those of Acromyrmex, is dependent on the strategies of soil conservation and/or the presence of grasses or undergrowth plants, which in turn may lead to the necessity of broad, systematic bait applications to control leaf-cutting ants (Zanetti et al. 2003a).

Forest plantations are investing in the development of techniques for the handling and application of bait, and they have made efforts to train workers and improve the equipment used in these tasks. Following the proper techniques, the bait applications are planned and performed by trained personnel while considering the safety and health of workers along with environmental impacts. Furthermore, labor laws in Brazil provide a high level of security that minimizes exposure to workers, especially those involved in chemical applications.

The behavioral responses of the insects to bait application vary with the environmental conditions, even between nests of the same species of leaf-cutting ant. In combatting the pests, environmental conditions should be evaluated when identifying the best method and time to apply bait in order to reduce adverse effects on non-target organisms. For example, some ant species, such as Acromyrmex laticeps nigrosetosus (Forel, 1908) demonstrate predominantly nocturnal activity. Their activity correlates negatively with air temperature and positively with relative humidity (Araújo et al. 2002). On the other hand, the activity of Acromyrmex landolti balzani (Emery, 1890) occurs in the afternoon (Poderoso et al. 2009). Moreover, the nocturnally active $A$. cephalotes workers are smaller than the diurnally active ones, although they exhibit better foraging performance. This is probably due to fewer ants crowding the trails (Yackulic and Lewis 2007).

While both the localized and systematic methods of bait application affected the ant population, the systematic method had the highest impact on species diversity of non-target ants in Eucalyptus plantations over time (Ramos et al. 2003). A systematic application is made once a year but not across the entire area, which allowed non-target species within the plantations and surrounding areas to recover their populations.

\subsection{Development of control alternatives using biological and/or non-chemical methods}

Alternative techniques to control leaf-cutting ant nests have been pursued. One of the FSC suggestions is the use of spinosad, a new insecticide class considered to have a low risk. The product activates the enzyme acetylcholinesterase and extends the responses to acetylcholine, which in turn over-stimulates the nervous system of the insect (California Department of Pesticide Regulation 2002). While colonies of Solenopsis invicta Buren, 1972 were not killed when treated with the spinosad-based bait in the laboratory, in the field, a mortality rate of $17 \%$ was observed (Oi and Oi 2006). Because the ants distribute the spinosad through trophallaxis (Barr 1997), the colony size and the foraging rate explain the low efficiency of this product (Oi and Oi 2006). Leaf-cutting ant nests, particularly of the genus Atta, are large and their control is inefficient when only soldiers and workers of the colony are killed, while the queen remains alive. After a period of decline, the nest will return to normal activity; this is similar to the process that occurs when chemical powder applications with deltamethrin are used (Mariconi et al. 1981). Furthermore, spinosad application may reduce the frequency and diversity of other ant groups in the plantations (Pereira et al. 2010).

Other recommendations proved to be ineffective in controlling the leaf-cutting ants in the field. Boric acid causes 
mortality of Atta sexdens rubropilosa workers, but it does not control the colony (Takashi-Del-Bianco 2002). A lower survival rate of workers of this species in vitro was found with boric acid when tested at different concentrations (Sumida et al. 2010). The control of leaf-cutting ants using diatomaceous earth, a low-toxicity insecticide used for pest control in stored products, houses and gardens (Quarles 1992), was very low compared to sulfluramid granulated baits (Ferreira-Filho et al. 2015). Plant extracts have also been tested for controlling leaf-cutting ants. The use of cassava (Manihot esculenta Crantz.) (Euphorbiaceae) extracts, as recommended by the FSC, was unsuccessful. Cassava is defoliated by several ant species in Brazil, including $A$. sexdens, A. cephalotes, A. laevigata, Acromyrmex rugosus (F. Smith 1858) and Acromyrmex octospinosus (Reich, 1793) (Bellotti and Schoonhoven 1978; Blanton and Ewel 1985; Rando and Forti 2005), indicating that this plant may not be toxic for their cultivated fungus or ants. Moreover, extracts of Carapa guianensis Aubl. (Meliaceae), Elaeis guineensis Jacq. (Arecaceae), Sesamum indicum L. (Pedaliaceae), Ricinus communis L. (Euphorbiacae), Azadirachta indica A. Juss. (Meliaceae), and Anacardium occidentale L. (Anacardiaceae) showed toxicity to A. sexdens rubropilosa workers, but in fogging, these extracts were not sufficient to control the nests in the field (Oliveira 2006). In addition, the essential oils of Citrus spp. seeds showed low toxicity to the fungus cultivated by the ants (Fernandes et al. 2002). The attractiveness of baits with extracts from Aleurites fordii Hemsley (Euphorbiacae) and Hovenia dulcis Thunberg (Rhamnaceae) plants has also been studied. Fungus-growing ants of various species carried the baits of Beauveria bassiana (Bals.) Vuill. with extracts of these plants (Specht et al. 1994). For FSC certification, the attractiveness of the bait is not a major problem, but rather the active ingredient that poses the challenge. For example, the loading of the base bait Metarhizium anisopliae was completed without the extracts from the attractive plant (Lopez and Orduz 2003).

Other control methods being tested include entomopathogens, such as fungi, nematodes and bacteria, although research is still being conducted in the laboratory and very few studies have been field tested thus far. The fungi B. bassiana, $M$. anisopliae (Metsch.) and Isaria farinosa (Holmsk.) Fr. caused an $80 \%$ mortality rate in $A$. sexdens sexdens soldiers after 4 days of inoculation (Loureiro and Monteiro 2005). Similar work was conducted with Atta bisphaerica and $A$. sexdens rubropilosa soldiers using eight isolates of $M$. anisopliae and six of B. bassiana, with four being virulent to the ant species (Castilho et al. 2010). Again, these efforts appear to be misdirected because the aim should be to control the symbiotic fungus or to suppress the queen instead of individual ants; there is no benefit in killing the soldiers. Another factor influencing the fungal action on the leaf-cutting ants is the bacterial biofilm on the cuticle of these insects. The biofilm releases antibiotic substances that prevent the growth of antagonistic fungi that can threaten the cultivated fungus. It also guarantees protection against pathogenic fungi, such as $M$. anisopliae, that could threaten the individuals themselves (Mattoso et al. 2012).

The use of $B$. thuringiensis has also been explored for controlling leaf-cutting ants. Bacillus thuringiensis was isolated from Ac. crassispinus and Ac. lundi (Guerin, 1838) and applied to individuals of the second species in the laboratory. The best results were found in two isolates, with $80 \%$ and $100 \%$ mortality rates, respectively, for the ants after seven days; however, tests were not conducted on entire nests in the field (Pinto et al. 2003).

The use of entomopathogens and plant extracts appears to misdirect the focus to controlling individuals rather than the whole nest. In fact, none of the evaluated recommendations was effective in controlling leaf-cutting ants in forest plantations. To develop effective low-toxicity ant insecticides, research must instead focus on substances that inhibit or destroy its symbiotic fungus which will kill the ants by starvation and thus control them properly. It is also essential that for efficient control, these substances (1) must act both by ingestion and contact, (2) are not repellents, (3) exhibit delayed toxic action, (4) are lethal at low concentrations and (5) halt cutting activities in the very first days after application. These factors are important because of the ant social organization and the high levels of hygiene previously mentioned.

Silvicultural practices may have a significant effect on leafcutting ants when combined with other techniques. For instance, native vegetation strips separating the stands may allow leaf-cutting ants to find alternative host plants and reduce the infestation on the plantation (Zanetti et al. 2000). A. sexdens rubropilosa was more attracted to the leaves of Gmelina arborea Roxb. (Lamiaceae) and Caesalpinia ferrea Mart. ex Tul. (Fabaceae) than to those of E. grandis in the laboratory (Peres Filho et al. 2002). Furthermore, leaf-cutting ants may discriminate between species of the same genus. Foragers of Acromyrmex nigrosetosus laticeps preferred E. urophylla and Eucalyptus camaldulensis Dehnh (Myrtaceae) compared with Eucalyptus cloeziana F. Muell. (Myrtaceae) (Marsaro Júnior et al. 2007). Tillage techniques are already being routinely used in the forestry sector for soil conservation purposes. Adopting tillage may delay the initial infestation as the crop residues are present in the area, but they do not stop the damage caused by the ants, which in turn requires other control methods. The localized application of bait may show lower efficiency in areas planted with minimum tillage. This is primarily because of the difficulty the ants face in locating and transporting the bait (Zanetti et al. 2003a). In addition, minimum tillage plantations may reduce nest monitoring efficiency, which may result in systematic control becoming mandatory in these areas. On the other hand, fertilized queen ants find it more difficult to establish new colonies 
in areas of minimum tillage and are more exposed to predators, which can reduce their colonization rate.

\section{Termite control}

\subsection{Reduction in the amount and number of pesticide applications}

The best way to improve fipronil applications is by evaluating the level of damage on the plantation through proper monitoring. This is important for obtaining information for correct decision-making in terms of application, especially in cases of post-planting. The data collected during monitoring included identification of damaged seedlings and correlations between the percentage of seedlings damaged in both treated and untreated areas. This information is related to different aspects of the area (e.g., implantation, reform, or leading), prior occupation of the area, amount of organic matter in the soil, planting season, soil type, etc., and can be used to determine the possible level of damage by termites in young plantations.

This information can also help with deciding whether to implement chemical control during plantation and in identifying ways to reduce unnecessary applications and reduce the amount of insecticide applied. After chemical treatment, the area should be monitored until the seedlings reach a size where termite damage to the roots is no longer important. While cardboard baits (Termitrap ${ }^{\circledR}$ ) were developed to monitor H. tenuis and other subterranean termite species (Almeida and Alves 1995), they are not an efficient decision-making tool. Furthermore, organic waste in the area, the density of the plant's root system and even soil moisture may produce biased results.

\subsection{Reduction in the side effects to non-target organisms and people}

The application of fipronil to control termites considers risks associated with applicators and non-target organisms. The planning and execution of seedling treatment, preventive control, and application after planting as a curative control all must follow specific safety, human and environmental health guidelines in addition to legal requirements. Moreover, seedling treatment reduces the amount of insecticide applied and is restricted to the root system, minimizing the impact on nontarget organisms.

\subsection{Development of control alternatives using biological and/or non-chemical methods}

The use of spinosad and borax for leaf-cutting ant control was not effective against termites, possibly for the same reasons previously given. The direct application of these products with injections on pallets infested with Cryptotermes brevis (Walker, 1853) achieved less than a $60 \%$ mortality rate for this insect (Woodrow et al. 2006).

The use of the minimum tillage is a suitable silvicultural practice to reduce termite damage to seedlings because the higher quantity of organic matter in the soil increases food availability for termites and reduces the likelihood of seedling damage. However, increased nutrient availability can promote the proliferation of these insects, making their control more difficult due to the presence of plant material. The availability of plant material in the soil makes it more difficult to identify the location of nests (Lopes et al. 2009) and prevents the ability of using traps for monitoring levels of infestation at the pre-planting stage.

\section{Final considerations}

There are a significant number of published alternatives to the use of deltamethrin, fenitrothion, fipronil, and sulfluramid to control leaf-cutting ants and termites in Brazil. Much of this research has been conducted in cooperation with the forestry industry in Brazil. The knowledge gap has been identified, and cooperative action plans have been developed between forestry companies and the academic community to meet the requirements of the conditions set by the FSC derogations.

Alternative techniques to control leaf-cutting ants remain ineffective as a replacement for the use of granulated baits with insecticide, which are currently prohibited and now in derogation by the FSC. However, it is necessary to continue the search for alternatives with better results. Alternatives from scientific studies have not yet acquired efficiency on a commercial scale. Many of these new techniques are focused on controlling the number of workers and soldiers for ants and termites; however, they will only be effective for controlling these pests in the field if the entire nest is treated as a single individual.

In Brazil, the process of certifying forest plantations has a specific feature that cannot be ignored. Government agency and broad legislative requirements that address chemicals for forest protection are very restrictive and aim to reduce problems associated with pesticide use in the country. Indeed, Brazil has updated the rules that regulate pesticides from the point of manufacture to the return of the empty product containers. As such, an environmental risk assessment may be a more suitable tool for the classification of products by FSC. In terms of identifying such environment risks, it would be valuable to account for general conditions relating to the use of chemicals, environmental factors, and the level of human exposure. 
Acknowledgments IPEF (Forestry Science and Research Institute) for the information provided. American Journal Experts corrected and rewrote the English of this manuscript.

\section{Compliance with ethical standards}

Funding We acknowledge "Conselho Nacional de Desenvolvimento Científico e Tecnológico (CNPq)", "Coordenação de Aperfeiçoamento de Pessoal de Nível Superior (CAPES)" and "Fundação de Amparo à Pesquisa do Estado de Minas Gerais (FAPEMIG)" for financial support.

\section{References}

Almeida AF (1982) O princípio do uso de micro-porta-iscas no controle das formigas cortadeiras em florestas implantadas. Silvicultura 8: 132-134

Almeida Reis M, Zanetti R, Scolforo JRS, Ferreira MZ (2010) Sampling plans for leaf-cutting ant nests (Hymenoptera: Formicidae) by the methods of strip transects and line transects on eucalyptus plantations. Rev Árvore 34:1101-1108. doi:10.1590/S010067622010000600016

Almeida JEM, Alves SB (1995) Seleção de armadilhas para Heterotermes tenuis em condições de laboratório e campo. Neotrop Entomol 24:619-624

Amaral-Castro NR, Zanetti R, Moraes JC, Zanuncio JC, Freitas GD, Santos MS (2004) Species of soil inhabiting termites (Insecta: Isoptera) collected in Eucalyptus plantations in the State of Minas Gerais, Brazil. Sociobiology 44:717-725

Anjos N, Moreira DD, Della Lucia TMC (1993) Manejo integrado de formigas em reflorestamentos. In: Della Lucia TMC (ed) As Formigas Cortadeiras, Viçosa, pp 212-241

Anjos N, Della Lucia TMC, Mayhé-Nunes AJ (1998) Guia prático sobre formigas cortadeiras em reflorestamentos. Editora Graff Cor, Ponte Nova

Araújo MS, Della Lucia TMC, Lima CA, Souza DJ, Petternelli EF (2002) Foraging activity of Acromyrmex laticeps nigrosetosus Forel (Hymenoptera, Formicidae) in Eucalyptus stands. Acta Sci Agron 24:1321-1325. doi:10.4025/actasciagron.v24i0.2370

Barr CL (1997) Efficacy of spinosad bait for the control of individual fire ant colonies. Fire ant applied research program reports 1994-1995. Texas Agric Ext Ser Bryan, Tx. https://insects.tamu.edu/fireant/ research/projects/pdf/97-99resultdemo.pdf. Accessed 11 Sept 2013

Basso VM, Jacovine LAG, Alves RR, Valverde SR, Silva FL, Brianezi D (2011) Evaluation of the influence of forest certification in compliance with environmental legislation in forest plantations. Rev Árvore 35:835-844. doi:10.1590/S0100-67622011000500009

Basso VM, Jacovine LAG, Alves RR, Nardelli AMB (2012) Contribution of forest certification in the attendance to the environmental and social legislation in Minas Gerais State. Rev Árvore 36: 747-757. doi:10.1590/S0100-67622012000400016

Bellotti A, Schoonhoven A (1978) Mites and insect pests of cassava. Annu Rev Entomol 23:39-67. doi:10.1146/annurev.en.23.010178. 000351

Berti Filho E (1993) Manual de pragas em florestas: cupins ou térmitas 3. $\mathrm{IPEF} / \mathrm{SIF}$

Blanton CM, Ewel JJ (1985) Leaf-cutting ant herbivory in successional and agricultural tropical ecosystems. Ecology 66:861-869. doi:10. 2307/1940548

Boaretto MAC, Forti LC (1997) Perspectivas no controle de formigas cortadeiras. Série Técnica IPEF 11

Caldeira MA, Zanetti R, Moraes JC, Zanuncio JC (2005) Distribuição espacial de sauveiros (Hymenoptera: Formicidae) em eucaliptais. Cerne 11:34-39
California Department Of Pesticide Regulation (2002) Facts about Spinosad. http://www.cdpr.ca.gov/docs/emon/epests/mexfly/fact sheet.pdf. Acessed 11 Sept 2013

Cantarelli ED, Costa EC, Zanetti R, Pezzutti R (2006) Acromyrmex spp. (Hymenoptera: Formicidae) sampling plan in Pinus spp. preplanting areas. Cienc Rural 36:385-390. doi:10.1590/S010384782006000200005

Cantarelli ED, Costa EC, Pezzutii R, Oliveira LS (2008) Quantificação de perdas no desenvolvimento de Pinus taeda após o ataque de formigas cortadeiras. Cienc Florest 18:39-45

Carnegie AJ, Stone C, Lawson S, Matsuki M (2005) Can we grow certified eucalypt plantations in subtropical Australia? An insect pest management perspective. NZ J For Sci 35:223-245

Castilho AMC, Fraga ME, Aguiar-Menezes EL, Rosa CAR (2010) Selection of Metarhizium anisopliae and Beauveria bassiana isolates pathogenic to Atta bisphaerica and Atta sexdens rubropilosa soldiers under laboratory conditions. Cien Rural 40:1243-1249. doi: 10.1590/S0103-84782010005000100

Constantino R (2002) The pest termites of South America: taxonomy, distribution and status. J Appl Entomol 126:355-365. doi:10.1046/ j.1439-0418.2002.00670.x

Cruz JM, Nogueira SB, Pereira AR, Neuwes BO (1984) Adaptação de uma motocicleta para termonebulização no controle de formigas saúvas (Atta spp.) em áreas reflorestadas de cerrado. Rev Árvore 8:104-111

Delabie JHC, Della Lucia TMC, Pastre L (2000) An experimental proto$\mathrm{col}$ for testing new formulations of granulate baits for the control of leaf-cutting ants Acromyrmex spp. and Atta spp. (Hymenoptera: Formicidae: Myrmicinae: Attini) in the field. Neotrop Entomol 29: 843-848. doi:10.1590/S0301-80592000000400029

Della Lucia TMC (2011) Formigas-Cortadeiras da Bioecologia ao Manejo. Editora UFV, Viçosa

Della Lucia TMC, Gandra LC, Guedes RNC (2013) Managing leafcutting ants: peculiarities, trends and challenges. Pest Manag Sci 70:14-23. doi:10.1002/ps.3660

Ericksson LO, Sallnäs O, Ståhl G (2007) Forest certification and Swedish wood supply. Forest Policy Econ 9:452-463. doi:10.1016/j.forpol. 2005.11.001

Fernandes JB, David V, Facchini PH, Silva MFGF, Rodrigues Filho E, Vieira PC (2002) Citrus seed oils extractions and their activity against leaf cutting ant Atta sexdens and its symbiotic fungus. Quim Nov. 25:1091-1095. doi:10.1590/S010040422002000700009

Ferreira-Filho PJ, Wilcken CF, Neves DA, Pogetto MHFAD, Carmo JB, Guerreiro JC, Serrão JE, Zanuncio JC (2015) Does diatomaceous earth control leaf-cutter ants (Hymenoptera: Formicidae) in the eucalyptus plantations? J Econ Entomol 108:1124-1128. doi:10.1093/ jee/tov066

Forest Stewardship Council (2007) FSC-GUI-30-001 V2-0 EN. FSC Pesticides Policy: Guidance on Implementation

Forest Stewardship Council (2012) FSC-GUI-30-001a V1-0 EN. FSC Pesticides Policy Guidance Addendum: List of Approved Derogations for use of "highly hazardous" Pesticides

Forest Stewardship Council (2015a) Global FSC certificates: types and distribution (September, 2015). http://www.fsc.org. Accessed 17 Sept 2015

Forest Stewardship Council (2015b) FSC List of 'highly hazardous' pesticides

Forest Stewardship Council (2015c) List of approved derogations for use of 'highly hazardous' pesticides

Forest Stewardship Council (2015d) Indicators and thresholds for the identification of 'highly hazardous' pesticides (HHP)

Govender P (2002) Management of insect pests: have the goalposts changed with certification? S For 195:39-45. doi:10.1080/ 20702620.2002.10434602 
Hernández JV, Jaffé K (1995) Dano econômico causado por populações de formigas Atta laevigata (F. Smith) em plantações de Pinus caribaea Mor. e elementos para o manejo da praga. Neotrop Entomol 24:287-298

IBA (2015) Relatório da Indústria Brasileira de Árvores, ano base 2014. http://www.iba.org/images/shared/iba_2015.pdf. Acessed 17 Sept 2015

Isering R, Neumeister L (2010) Recommendations regarding derogations to use alpha- cypermethrin, deltamethrin, fenitrothion, fipronil and sulfluramid in FSC certified forests in Brazil, 99 pp. Available at: "http://www.ipef.br/pccf/arquivos/TA_Rec_alpha-CypermethrinDeltamethrin-Fenitrothion-Fipronil-Sulfluramid_BR_2010.pdf'

Laranjeiro AJ, Alves JEM, Marques CG, Almeida AF (1986) Análise da distribuição de micro-porta-iscas em áreas de reforma de Eucalyptus spp., visando o controle de formigas cortadeiras (Atta spp., e Acromyrmex spp.). Companhia Agrícola e Florestal Santa Bárbara. Boletim Técnico

Lopes JLW, Saad JCC, Guerrini IA, Lopes CF (2009) Influência dos fatores bióticos e abióticos na sobrevivência de eucalipto em função do solo e do manejo de viveiro. Biotemas 22:29-38

Lopez E, Orduz S (2003) Metarhizium anisopliae and Trichoderma viride for control of nests of the fungus-growing ant, Atta cephalotes. Biol Control 27:194-200. doi:10.1016/S1049-9644(03)00005-7

Loureiro ES, Monteiro AC (2005) Pathogenicity of isolates of three entomopathogenic fungi against soldiers of Atta sexdens sexdens (Linnaeus, 1758) (Hymenoptera: Formicidae). Rev Árvore 29: 553-561. doi:10.1590/S0100-67622005000400007

Magistrali IC, Anjos N (2011) Avaliação de sauveiros externos em eucaliptais de Minas Gerais. Cienc Florest 21:349-354

Mariconi FAM, Filho JMAM, Moraes TSA (1981) Reunião técnica sobre: "Formigas cortadeiras em povoamentos florestais". Série Técnica IPEF 2

Marsaro Júnior AL, Molina-Rugama AJ, Lima CA, Della Lucia TMC (2007) Preferência de corte de Eucalyptus spp. por Acromyrmex laticeps nigrosetosus Forel, 1908 (Hymenoptera: Formicidae) em condições de laboratório. Cienc Florest 17:171-174

Mattoso TC, Moreira DDO, Samuels RI (2012) Symbiotic bacteria on the cuticle of the leafcutting ant Acromyrmex subterraneus subterraneus protect workers from attack by entomopathogenic fungi. Biol Lett 8:461-464. doi:10.1098/rsbl.2011.0963

Meidinger E (2011) Forest certification and democracy. Eur J For Res 130:407-419. doi:10.1007/s10342-010-0426-8

Mendes JEP (2004) Influência do desfolhamento causado por Costalimaita ferruginea e nível de dano econômico em Eucalyptus grandis. Thesis, Universidade Federal de Viçosa

Oi DH, Oi FM (2006) Speed of efficacy and delayed toxicity characteristics of fast-acting fire ant (Hymenoptera: Formicidae) baits. J Econ Entomol 99:1739-1748. doi:10.1093/jee/99.5.1739

Oliveira MFSS (2006) Controle de formigas cortadeiras (Hymenoptera: Formicidae) com produtos naturais. Thesis, Universidade Estadual Paulista

Overdevest C, Rickenbach MG (2006) Forest certification and institutional governance: an empirical study of forest stewardship council certificate holders in the United States. Forest Policy Econ 9:93102. doi:10.1016/j.forpol.2005.03.014

Parma LG, Ulhüa MA (1986) Combate de formiga na Companhia Agrícola e Florestal Santa Bárbara (CAF-SB). In: Pacheco P, Berti Filho E. (eds) Formigas cortadeiras e seu controle. IPEF

Passos CAM, Bufulin Junior L, Gonçalves MR (2006) Avaliação silvicultural de Tectona grandis L.f., em Cáceres - MT, Brasil: resultados preliminares. Cienc Florest 16:225-232

Pereira JL, Picanço MC, Da Silva AA, De Barros EC, Da Silva RS, Galdino TVDS, Marinho CGS (2010) Ants as environmental impact bioindicators from insecticide application on corn. Sociobiology 55: $153-164$
Peres Filho O, Dorval A, Berti Filho E (2002) Preferência de saúva limão, Atta sexdens rubropilosa Forel, 1908 (Hymenoptera, Formicidae) a diferentes espécies florestais, em condições de laboratório. Cienc Florest 12:1-7

Pikart TG, Souza GK, Serrão JE, Zanuncio JC (2011) Leafcutter ants: A small dispersal agent of the invasive plant Murraya paniculata. Weed Res 51:548-551. doi:10.1111/j.1365-3180.2011.00881.x

Pinto MLN, Azambuja AO, Diehl E, Fiuza LM (2003) Pathogenicity of Bacillus thuringiensis isolated from two species of an Acromyrmex (Hymenoptera, Formicidae). Braz J Biol 63:301-306. doi:10.1590/ S1519-69842003000200015

Poderoso JCM, Ribeiro GT, Gonçalves GB, Mendonça PD, Polanczyk RA, Zanetti R, Serrão JE, Zanuncio JC (2009) Nest and foraging characteristics of Acromyrmex landolti balzani (Hymenoptera: Formicidae) in Northeast Brazil. Sociobiology 54:361-371

Quarles W (1992) Diatomaceous earth for pest control. Monitoring the field of pest management 14 completar esta referencia

Ramos LS, Marinho CGS, Zanetti R, Delabie JHC, Schlindwein MN (2003) Impacto de iscas formicidas granuladas sobre a mirmecofauna não-alvo em eucaliptais segundo duas formas de aplicação. Neotrop Entomol 32:231-237

Rando JSS, Forti LC (2005) Ocorrência de formigas Acromyrmex Mayr, 1865 em alguns municípios do Brasil. Acta Sci Biol Sci 27:129133. doi:10.4025/actascibiolsci.v27i2.1322

Reis Filho W, Santos F, Strapasson P, Nickele MA (2011) Danos causados por diferentes níveis de desfolha artificial para simulação do ataque de formigas cortadeiras em Pinus taeda e Eucalyptus grandis. Pesqui Florest Bras 31:37-42

Rolando CA, Watt MS, Zabkiewicz JA (2011) The potential cost of environmental certification to vegetation management in plantation forests: a New Zealand case study. Can J For Res 41:986-993. doi: 10.1139/x11-022

Rua D, Santos EF, Massaroth LFM (2009) Produto Certificado FSC: conheça as normas para produzir e comercializar. Imaflora, Piracicaba

Schroth G, Coutinho P, Moraes VHF, Albernaz AL (2003) Rubber agroforests at the Tapajós river, Brazilian Amazon - environmentally benign land use system in an old forest frontier region. Agric Ecosyst Environ 97:151-165. doi:10.1016/S0167-8809(03)00116-6

Sossai MF, Zanuncio JC, Leite HG, Zanetti R, Serrão JE (2005) Transects to estimate the number of leaf-cutting ant nests (Hymenoptera: Formicidae) in Eucalyptus urophylla plantations. Sociobiology 46: 667-676

Souza A, Zanetti R, Calegario N (2011) Economic damage level for leafcutting ants in function of the productivity index of eucalyptus plantations in an Atlantic Forest region. Neotrop Entomol 40:483-488. doi:10.1590/S1519-566X2011000400012

Specht A, Diehl-Fleig E, Da Silva ME (1994) Atratividade de iscas de Beauveria bassiana (Bals.) Vuill. a formigas do gênero Acromyrmex (Hymenoptera: Formicidae). Neotrop Entomol 23:99-104

Sumida S, Silva-Zacarin ECM, Decio P, Malaspina O, Bueno FC, Bueno OC (2010) Toxicological and histopathological effects of boric acid on Atta sexdens rubropilosa (Hymenoptera: Formicidae) workers. J Econ Entomol 103:676-690. doi:10.1603/EC09159

Tabaković-Tošić M, Koprivica M, Tošić D, Golubović-Ćurguz V (2011) Biological efficacy of the ecotoxically favourable inseticides and their mixture in the control of gipsy moth. Afr J Biotechnol 10: 4656-4664

Takashi-Del-Bianco M (2002) Toxicidade de extratos orgânicos foliares de Canavalia ensiforms L. e de alguns princípios ativos de inseticidas comerciais para operárias de Atta sexdens L., 1758 (Hymenoptera: Formicidae) isoladas do formigueiro. Thesis, Universidade Estadual Paulista

Ukan D (2008) Avaliação qualitativa e quantitativa de micro-porta-iscas para o controle de formigas cortadeiras, em plantios de Eucalyptus 
urograndis submetidos a diferentes cronogramas silviculturais. Dissertation, Universidade Federal do Paraná

Wilcken CF, Raetano CG (1995) Controle de cupins em florestas. In: Berti Filho E, Fontes LR (eds) Alguns aspectos atuais da biologia e controle de cupins. FEALQ, Piracicaba

Woodrow RJ, Grace JK, Oshiro RJ (2006) Comparison of localized injections of spinosad and selected insecticides for the control of Cryptotermes brevis (Isoptera: Kalotermitidae) in naturally infested structural mesocosms. J Econ Entomol 99:1354-1362. doi:10.1093/ jee/99.4.1354

Yackulic CB, Lewis OT (2007) Temporal variation in foraging activity and efficiency and the role of hitchhiking behaviour in the leafcutting ant, Atta cephalotes. Entomol Exp Appl 125:125-134. doi: 10.1111/j.1570-7458.2007.00606.x

Zanetti R, Vilela EF, Zanuncio JC, Leite HG, Freitas GD (2000) Influence of the cultivated species and of the native vegetation on leaf-cutting ant nests density in eucalyptus plantations. Pesqui Agropecu Bras 35:1911-1918. doi:10.1590/S0100-204X2000001000001

Zanetti R, Zanuncio JC, Mayhé-Nunes AJ, Medeiros AGB, Souza-Silva A (2003a) Systematic control of leaf-cutting ants in areas with eucalyptus stands under minimum cultivation system. Rev Árvore 27: 387-392. doi:10.1590/S0100-67622003000300016

Zanetti R, Zanuncio JC, Souza-Silva A, Abreu LG (2003b) Efficiency of a granulated bait applied over the nests of Atta sexdens rubropilosa (Hymenoptera: Formicidae). Rev Árvore 27:407-410. doi:10.1590/ S0100-67622003000300019
Zanetti R, Zanuncio JC, Santos JC, Silva WLP, Ribeiro GT, Lemes PG (2014) An overview of integrated management of leaf-cutting ants (Hymenoptera: Formicidae) in Brazilian forest plantations. Forest 5: 439-454. doi:10.3390/f5030439

Zanuncio JC, Couto L, Santos GP, Zanuncio TV (1992) Eficiência da isca granulada Mirex-S, à base de sulfluramida, no controle da formigacortadeira Atta laevigata (Hymenoptera; Formicidae). Rev Árvore 3:357-361

Zanuncio JC, Couto L, Zanuncio TV, Fagundes M (1993) Eficiência da isca granulada Mirex-S (sulfluramida $0,3 \%$ ) no controle da formigacortadeira Atta bisphaerica (Hymenoptera; Formicidae). Rev Árvore 17:85-90

Zanuncio JC, Santos GP, Firme DJ, Zanuncio TV (1997) Uso da isca granulada com Sulfluramida 0,3\%, no controle de Atta sexdens rubropilosa Forel, 1908 (Hymenoptera: Formicidae). Cerne 3: 161-169

Zanuncio JC, Zanuncio TV, Pereira JMM, Oliveira HN (1999) Control of Atta laevigata (Hymenoptera: Formicidae), with landrin-f bait, in areas previously covered with eucalyptus. Cienc Rural 29:573576. doi:10.1590/S0103-84781999000400001

Zanuncio JC, Lopes ET, Leite HG, Zanetti R, Sediyama CS, Fialho MDCQ (2004) Sampling methods for monitoring the number and area of colonies of leaf-cutting ants (Hymenoptera: Formicidae) in Eucalyptus plantations in Brazil. Sociobiology $44: 337-344$ 